\title{
Biochemical Changes Induced by Butachlor and Machete 50\% EC to the Freshwater Fish Channa punctata (Bloch)
}

\author{
P. Bhaskara Tataji ${ }^{1}$, M. Vijaya Kumar ${ }^{2}$ \\ ${ }^{1}$ Department of Zoology, Acharya Nagarjuna University, Nagarjunanagar-522 510, A.P. India \\ ${ }^{2}$ Sri A.S.N.M. Government College (Autonomous), Palakol, West Godavari District-534260, A.P. India
}

\begin{abstract}
An acetanilide group herbicide Butachlor and the commercial formulation Machete (50\% EC) both are tested to the fish Channa punctata (Bloch). The $L_{50}$ values for 96 hours are $160 \mathrm{ppb}$ for Butachlor and $356 \mathrm{ppb}$ for Machete. The fish exposed to $1 / 5$ th of $L C_{50}$ values of 96 hours, for 8 days and biochemical changes due to enzyme related after the exposure are determined. The decrement changes are observed in total glycogen and proteins of tissues including the nucleic acids, Deoxyribonucleic acid (DNA) and Ribose nucleic acid (RNA) whereas the lactate dehydrogenase (LDH) activity was elevated. The biochemical alterations affect the survival of the organisms and will be the pathway as sign of toxicity at tissue level before the effect is at organism level causing acute toxicity.
\end{abstract}

Keywords: Channa punctata, Biochemical changes, Butachlor, Machete 50\% EC.

\section{Introduction}

India is primarily an agricultural country. The most important concern associated with agricultural production is the problem of weeds and insects. Inspite of extensive efforts, all the weeds and insects cannot be controlled through biological control. Hence, use of chemicals, pesticides/ insecticides/herbicides, is indispensable in modern agricultural technology to control pests for production of more food and management of public health, especially in developing countries.

Pesticides contribution to the global environment pollutants has reached great heights due to industrial and intensive agricultural activities [1]. With the increase in pesticide consumption, the herbicide classification tops the group due to their integral part in modern intensive cropping systems [2].

Butachlor was the first rice herbicide to be introduced in India. It is chemically 2-chloro-N-(2, 6- diethylphenyl) acetanilide, used mainly in rice paddy fields to control perennial grasses and some broad-leaf weeds. It is estimated that in Asia alone it is used more than $4.5 \times 10^{7 \mathrm{Kg}}$ per year [3]. Studies have explained pollutants such as pesticides directly and indirectly (by runoff, rainfall, floods and etc.) released into aquatic environment [4]. Therefore they can affect on target and non-target organisms [5]. Both physiological and biochemical processes induced by pollutants can be caused damage on aquatic organisms [6]. Hence in the present study, an attempt is made by taking a much used pesticide locally, Butachlor as Machete the commercial formation to the fish Channa punctata by exposing in sublethal concentration.

\section{Materials and Methods}

Channa punctata (6-9 cm in length; 6.5 - $7.5 \mathrm{~g}$ in weight) were brought from local area and acclimatized at $28 \pm 2{ }^{\circ} \mathrm{C}$ in the laboratory for 8 to 10 days. During acclimatization, the fish were fed with groundnut oil cake, maize powder, coconut oil cake and rice bran. The feeding was stopped one day prior to the experiment. Such acclimatized fish were exposed for 8 days to $1{ }^{\text {th }}$ of $\mathrm{LC}_{50} 96$ hours of both Butachlor technical grade and Machete 50\% emulsifiable concentration (EC) i.e. $32 \mathrm{ppb}$ and $71.2 \mathrm{ppb}$ for both technical and 50\% EC respectively. Tissues of Channa punctata (gill, liver, brain and muscle) were taken for estimation of the biochemical changes to study the effects.

The total protein by the method of [7], glycogen [8], DNA and RNA [9][10] were estimated respectively. The activity of lactate dehydrogenase ( $\mathrm{LDH})$ was estimated by the method of [11] with the modifications suggested by [12].

\section{Results and Discussion}

Glycogen: The experimental results of the glycogen content in fish tissues are given in Fig. 1.

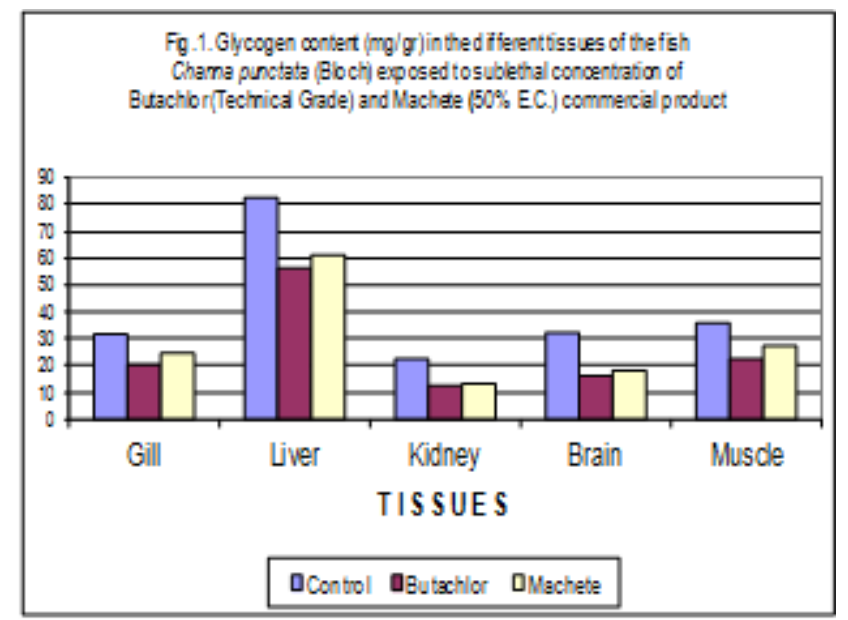

The decrement when compared to control is evident since the prime energy source is glucose only, where it will be reserve pathway as glycogen. Both the toxicants technical as well as Machete decreased the glycogen in all the tissues tested and 


\section{International Journal of Science and Research (IJSR) ISSN (Online): 2319-7064 \\ Index Copernicus Value (2013): 6.14 | Impact Factor (2014): 5.611}

the decrease in different tissues is in the following order: Liver $>$ Muscle $>$ Brain $>$ Gill $>$ Kidney

The significant decrease in liver, the vital organ and the site of the metabolism induces the toxicant effect overall in organ coordination and ultimately and definitely cannot lead a normal life. The earlier report in this line was observed in freshwater fish liver of Tor tor exposed to butachlor showed significant decrease in glycogen, slight decrease in protein [13]. Muscle glycogen levels were also significantly low in the group of fishes exposed to butachlor [14].The fall of glycogen is due to utilization, to meet the extra demand of energy during stress conditions. Since the glycogen is considered to be the first among the organic nutrients to be affected and decreased under any physiological stress conditions imposed on the animal [15].

According to [16] studied the impact of dairy effluent on biochemical parameters of Oreochromis mossambica by the acute toxicity test and reported that at $\mathrm{LC}_{50}$ for $96 \mathrm{hrs}$ of dairy effluent, it was found to be $8 \%$ decrease. Carbohydrates were found to be $18.75 \mathrm{mg} / 100 \mathrm{mg}$ in liver when compared to the control values of $2.89 \mathrm{mg} / 100 \mathrm{mg}$ there by indicating that the dairy effluent influenced the carbohydrates content in gills and muscle as decrement. [17] reported that after 6 hours of exposure to $6.5 \mathrm{ppm}$ of Butachlor, the glycogen content in snail (Bimphalaria alexriadrina), soft tissues, were significantly reduced. [18] reported that when the freshwater fish Labeo rohita was exposed to the pesticide mixture of Monocrotophos and Fenvalerate (1:4), total carbohydrates were decreased.

Hence, it can be interpreted that pesticides as pollutants cause disturbance of glycogen metabolism, where at the tissues level, a biochemical change can be established.

Proteins: The changes in protein content observed in various tissues of the fish at sublethal concentrations after exposure to the toxicants Butachlor and Machete are graphically represented as Fig. 2.

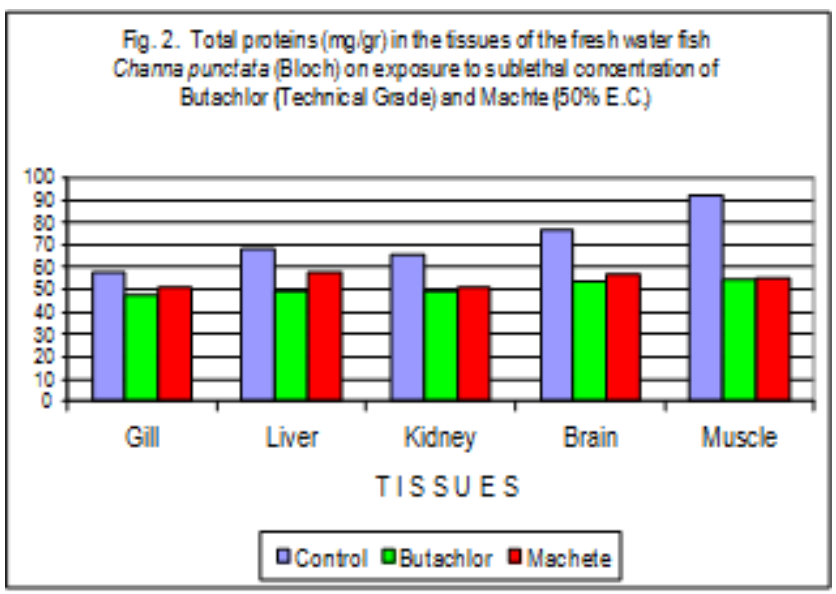

The lyotropic series of the protein content in control is in the order in control: Muscle $>$ Brain $>$ Liver $>$ Kidney $>$ Gill whereas exposed to sublethal concentrations of Machete $50 \%$ EC, protein content was found to be decreased in most of the tissues of Channa punctata (Bloch), the lyotropic series in terms of decrement in protein content was: Liver $>$ Brain $>$ Muscle $>$ Kidney $>$ Gill

Decrease in protein content may be due to increased proteolysis [19] or it may be due to metabolic utilization of the ketoacids to glucogenesis pathway for synthesis of glucose [20]. The alteration in protein value may also be related to some structural changes in the liver, the arrangement of hepatic words leading to the alteration of liver metabolism

According to [16] studied impact of dairy effluent on biochemical parameters of Oreochromis mossambica by acute toxicity test and reported that at $\mathrm{LC}_{50}$ for $96 \mathrm{hrs}$ affect protein and it influenced the increase of metabolism which is impaired and found to be $87.5 \mathrm{mg} / 100 \mathrm{mg}$ in gills, 3.46 $\mathrm{mg} / 100 \mathrm{mg}$ in muscle and $12.75 \mathrm{mg} / 100 \mathrm{mg}$ in liver when compared to the control value of $11.87 \mathrm{mg} / 100 \mathrm{~g}$, in gills and muscle.

According to [21] the study was to evaluate the acute (96 hrs) subchronic (7 \& 14 days) and chronic (21 days) impact of the pesticidal mixture (Endosulfan; Malathion and Agrafun 1:1:1) on total protein content in the stomach, intestine and ovary of the fish Clarias batrachus. A concentration of $0.088 \mathrm{ppm}$ was used as the acute dose whereas $0.011,0.022$ and 0.044 ppm's were used doses as subchronic and chronic exposure. The reduced protein profiles estimated in the exposed fish were found to be dose duration dependent. Except the stomach in which significant alteration is revealed at acute $(0.088 \mathrm{ppm})$ and in one of the sublethal doses $(0.011 \mathrm{ppm})$, the reduction in the total protein content was maximum in the intestine (50\%) followed by ovary (52\%) and stomach (25\%). [17] reported that after 6 hours exposure to $6.5 \mathrm{ppm}$ of Butachlor, the protein contents in the snail (Biomphalaria alevandrina) soft tissues were significantly reduced. [22] studied the biochemical changes in the fresh water Snail Pila globosa (Suaison) exposed to sublethal concentrations of the herbicide, Butachlor (26.6 ppm) in the ambient medium, at $3,6,12,24$ and $48 \mathrm{~h}$ intervals and found a significant decrease in total soluble proteins. The decrease in total soluble proteins under Butachlor stress appears to be common in fish and other higher animals also [23]. The increase in free amino acids (FAA) coupled with inhibition of transaminase also suggests lesser feeding of keto-acids into the TCA cycle in spite of the greater availability of amino acids and a failure of their participation for greater needs of energy synthesis during Butachlor exposure[22].

As per the earlier reports compared to present work, proteins are drastically effected and are the alternative source of energy for fish. Hence, even though sublethal concentration for a time can be a lethal and are dangerous.

Deoxyribonucleic Acid: The DNA content in various tissues of Channa punctata (Bloch) exposed to pesticidal concentrations, along with control was graphically represented in Fig. 3. 


\section{International Journal of Science and Research (IJSR) \\ ISSN (Online): 2319-7064}

Index Copernicus Value (2013): 6.14 | Impact Factor (2014): 5.611

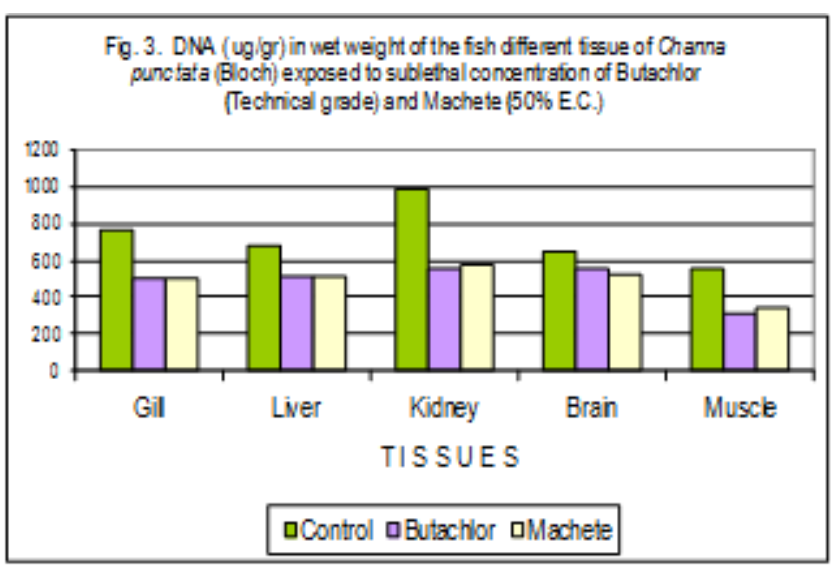

The lyotropic gradation series in order given below for control are: Kidney > Gill > Liver > Brain > Muscle, whereas for Butachlor (Technical grade) and Machete (50\%), the DNA content was significantly decreased in all the tissues of the test fish, the lyotropic series in terms of decrement DNA content are: Kidney $>$ Brain $>$ Liver $>$ Gill $>$ Muscle. The DNA content in all the tissues of Channa punctata (Bloch) showed very significant decrease over the control, the decrease was observed in both Technical and E.C. formulations.

Nucleic acids have an important role in all biological activities and also regulate the biological synthesis of proteins which are structural and functional. Any alteration in Nucleic acid content leads to variations of protein profile. In the present work decreased values were observed in all the tissues that are exposed to toxicants (Fig. 3 and 4) which also agree with the earlier reports [24] and [25].

According to [26] studies on Cirrhinus mrigala to evaluate the toxic effect of butachlor on chromosomal aberration clearly revealed the genotoxic potential of butachlor even at low dose level (1.0 ppm) interferes with cellular activities in fishes at genetic level, inducing chromosomal aberrations.

[27] reported histo-chemical observations on nucleic acids (RNA \& DNA) in the stomach and intestine of Channa punctata (Bloch) after the treatment with endosulfan and diazinon pesticides. A significant decrease in nucleic acids of gastro intestine tract was reported. However, the decrease in nucleic acids content after diazinon treatment was not significant. The treatment of endosulfan in mucosa and submuviral tissues shows very little impact on nucleic acid content. However, in diazinon treatment the DNA was completely decreased.

Butachlor (except 0.50 and $0.75 \%$ ) induced chromosomal breaking increased with an increase in concentration of the herbicide. Chromosome break is more generally considered to involve DNA molecule responsible for linear continuity of chromosome and may arise due to unfinished synthesis or mas repair of DNA [28].

[29] studied the DNA damage by butachlor in Cyprinus carpio using single cell gel electrophoresis and found that significant increase in genetic damage index was observed in treatments compared with control samples. The results also showed the genotoxicity potential of butachlor on fish.
Ribose Nucleic acid (RNA) : The amount RNA estimated in different tissues after exposure to pesticide concentration in Fig. 4.

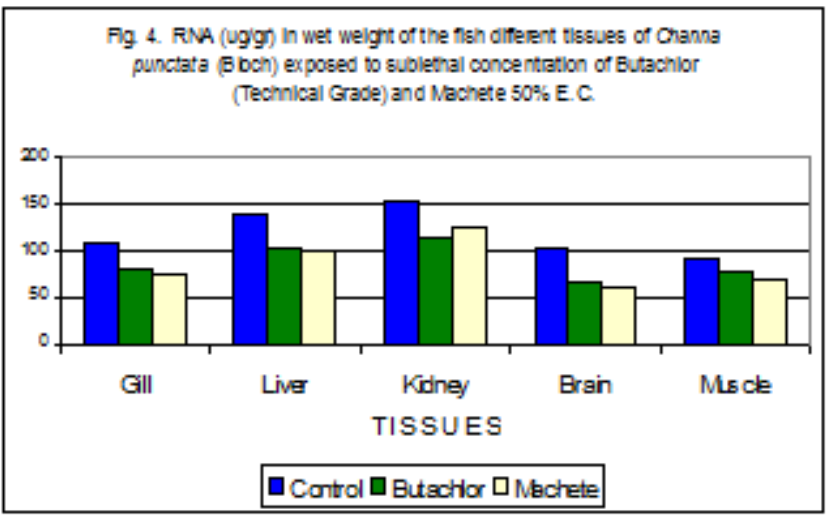

In control, the RNA content in kidney was highest followed by liver, gill and brain. The lyotropic series in terms of increment in RNA content was: Kidney $>$ Liver $>$ Gill > Brain $>$ Muscle, whereas exposed to sublethal concentrations of Butachlor (technical grade), the RNA content was decreased in all tissues of Channa punctata (Bloch): Kidney $>$ Liver $>$ Gill $>$ Muscle $>$ Brain. Similarly in all tissues exposed to sublethal concentration of Machete (50\% EC), the RNA content was decreased: Kidney $>$ Liver $>$ Gill $>$ Muscle > Brain.

The RNA content in all the tissues Channa punctata (Bloch) showed a very significant decrease over the control, the decreasing trend was more significant in sublethal concentrations. The level of RNA in liver is higher than brain, gill, muscle and kidney. The RNA levels reflect the intensity to protein synthesis [30] and metabolic activity of tissue [31]. Pollutants alter the behavioural pattern, growth, reproductive potential and resistance to disease in aquatic organisms by altering the biochemical changes [32]. Chromosomal and mitotic aberrations induced by the three herbicides (Butachlor, Benthocarb and Fluchloralin) tested are similar to aberrations induced by other pesticides [33][34][35].

Lactate dehydrogenase (LDH): Amount of Lactate dehydrogenase along with per cent changes over the control represented in Fig. 5.

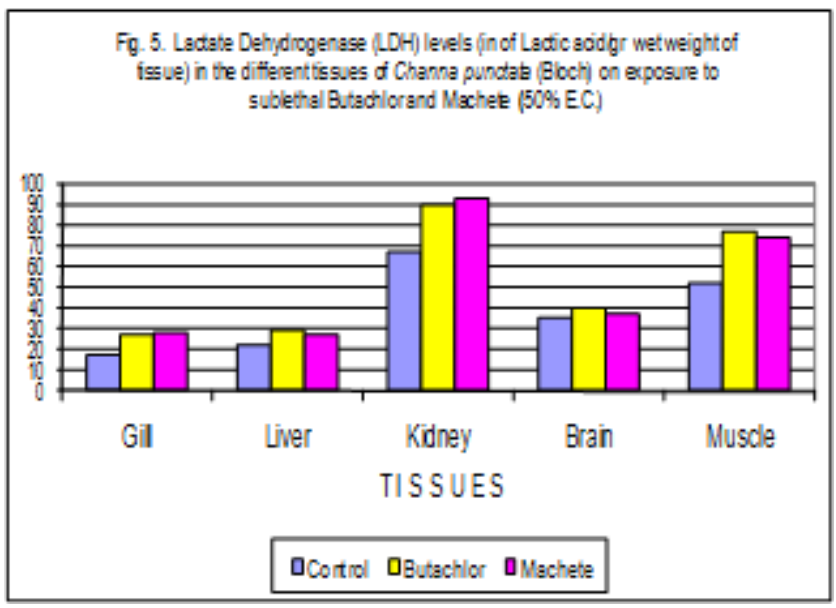




\section{International Journal of Science and Research (IJSR) \\ ISSN (Online): 2319-7064 \\ Index Copernicus Value (2013): 6.14 | Impact Factor (2014): 5.611}

The LDH levels in the control tissues of the Channa punctata (Bloch) are highest in kidney followed by muscle, brain, liver and gill. The lyotrophic series of the level of LDH is as follows: Muscle $>$ Kidney $>$ Brain $>$ Liver $>$ Gill, where exposed to sublethal concentrations of Butachlor (technical grade) increased levels of LDH were observed in all the tissues of Channa punctata (Bloch). The lyotropic series in terms of elevation in LDH content was: Kidney > Muscle $>$ Brain $>$ Liver $>$ Gill, whereas exposed to sublethal concentrations of Machete (50\% EC), increased LDH levels were observed in all the tissues of Channa punctata (Bloch). The lyotropic series in terms of elevation in LDH content was: Kidney $>$ Muscle $>$ Brain $>$ Gill $>$ Liver.

The increased lactate levels after exposure to sublethal concentrations indicate a decrease in aerobic and increase anaerobic respiration. [36] and [37] reported similar observations in in vivo by the polychlorinated biphenyls. The increased lactate and decreased pyruvate levels are due to increase muscular activity [38].

[39] reported a decrease in pyruvate levels and increase in lactate levels in Channa punctata (Bloch) exposed to sublethal and lethal concentrations of pesticide of fenvalerate. This can be attributed to toxic stress resulting in the inhibition of pyruvate oxidation under hypoxic conditions which indicates the shifting the aerobic to anaerobic respiration. LDH levels increased in the tissues due to stress when exposed the toxicant.

[40] stated that the increased LDH activity during anaerobic respiration is to meet the energy demands in the absence of aerobic respiration. The $\mathrm{LDH}$ activity increased in gill, brain, muscle and liver tissues of Channa punctata exposed to sublethal concentrations of metasystox [41] and phosphomidon in Clarias batrachus [42]. [43] reported increased LDH activity in gill, brain, muscle and liver tissues of Labeo rohita exposed to sub-lethal concentrations of metasystox. [44] explained that the raise of LDH activity increases the permeability of cells as well as necrosis.

Similar observations on LDH activity were made under pesticides stress by [45]. The disturbance in protein metabolism and LDH activity were resulted due to the exposure to pesticides. Thus even in sublethal concentrations the toxicants acting as a slow poison.

Therefore, the results of these investigations suggest a serious concern towards the potential danger of butachlor for aquatic organisms and the environment suggesting judicious and careful use of this pesticide in agricultural area.

\section{References}

[1] C.S.Chen, T.W. Wu,H.L.Wang,S.H.Wu,C.J.Tien, "The ability of immobilized bacterial consortia and strains from river biofilms to degrade the carbamate pesticide methomyl", International Journal of Environmental Science and Technology. doi:10.1007/s13762-014-0675z, 2014

[2] P.J.Sarma,R.Kumar,K.Pakshirajan, "Batach and continuos removal of copper and lead from aqueous solution using cheaply available agricultural waste materials", Internatinal Journal of Environmental Research. 9(2), pp 635-648, 2015.

[3] B.Ateeq,M.Abul farah,M.N.Ali,W.Ahmad, "Induction of micronuclei and erythrocyte alterations in the catfish Clarias batrachus by 2,4-dichlorophenoxyacetic acid and butachlor", Mutational Research. 518,pp 135-144, 2002.

[4] T.Polard, S.Jean, L.Gauthier, C.Laplanche, G.Merlina, J.M.Sánchez-Pérez, E.Pinelli, "Mutagenic impact on fish of runoff events in agricultural areas in south-west France", Aquatic Toxology.101, pp126- 134, 2011.

[5] T.Cavas, "In vivo genotoxicity evaluation of atrazine and atrazine-based herbicide on fish Carassius auratus using the micronucleus test and the comet assay", Food and Chemical Toxicology, 49,pp 1431-1435,2011.

[6] D.Ali,S.Kumar, "Long-term genotoxic effect of monocrotophos in different tissues of freshwater fish Channa punctatus (Bloch) using alkaline single cell gel electrophoresis", Science of the total environment. 405,pp 345-350, 2008

[7] O.H.Lowry, N. J. Rosebrough, A.L. Farr and R.J. Randall, "Protein measurement with Folin phenol reagent", Journal of Biological Chemistry.193,pp 265275,1951.

[8] A.Kemp,J.M.Adrinene, Kits and Van Hejnenga, "A colorimetric method for the determination of glycogen in tissues", Journal of Biological Chemistry. 56,pp 646648, 1954

[9] D.G.Searchy, A.J.MacLennis, "Determination of DNA by the Barton Diphenylanine technique", in experiments and techniques in parasitology. (eds: A.J.Mac Lnnis and M.Voge) W.H. Freeman and Co., San-Franscisco, pp190-191,1970a.

[10] D.G.Searchy, A. J. MacLnnis, "Determination of RNA by Dische orcinol technique" in Experiments and techniques in parasitology (eds A.J. Mac Lnnis and M.Voge). W.H. Freeman and Co., San-Francisco,pp 189-190 1970b.

[11] T.N.Srikanthan, C.R.Krishna Murthy, "Tetrazolium test for dehydrogenases", Journal of Scienctific and Industrial Research, 14,pp 206,1955.

[12] S.Govindappa,K.S. Swami, “ Electrophoretic characteristics of subcellular components and their relation to enzyme activities in amphibian muscle", Indian Journal of Experimental Biology. 3(4),pp 209212,1965.

[13] Vishal Rajput, Mayuri Pachori, Swati Singh, "Biochemical changes induced by Butachlor in the liver of freshwater fish Tor tor (Ham.)", International Journal of Engineering Sciences. December, 3,pp 225-229, 2014.

[14] Abhay Singh Yadav, Anita Bhatnagar, Manjeet Kaur, "Assessment of genotoxic effects of butachlor in fresh water fish Cirrhinus mrigala (Hamilton)", Research journal of Environmental Toxicology. 4(4) pp 223-230, 2010.

[15] J.R.Clarke, N.K. Patrick, D.P. Middugh, J.C. Moore, "Relative sensitivity of six estuarine fish to carbophenonothen, chlorpyrifos and fenvalerate", Ecotoxicology and Environmental Safety. 10, pp 382390, 1985.

[16] C.M.Noorjahan,Dawood Sharay, D. Nausheen, "Impact of dairy effluent on biochemical constituents of fish 


\section{International Journal of Science and Research (IJSR) \\ ISSN (Online): 2319-7064 \\ Index Copernicus Value (2013): 6.14 | Impact Factor (2014): 5.611}

Oreochromis mossambicus", Journal of Ecotoxicology Environmental Monitoring. 13(3),pp 227-231, 2003.

[17] A.A. Tantawy, "Effect of two herbicides in some biological and biochemical parameters of Biomphalaria alexandrina", Journal of Egypt Social Paragitology. 32(3),pp 837-847,2002.

[18] K.S.Tilak, K.Veeraiah, G.V.Ramana Kumari, "Biochemical changes induced in freshwater fish Labeo rohita (Hamilton) exposed to pesticide mixture" Asian Journal of Microbiology Biotechnology and Engneering Science. 3(4), pp 315-319, 2001.

[19] D.V.Muley, D.M.Karanjkar, S.V.Maske, "Impact of industrial effluents on the biochemical composition of freshwater fish Labeo rohita", Journal Environmental Biololgy. 28(2),pp 245-249,2007.

[20] B. Schmidt-Nielson, "Comparative Physiology of cellular ion and volume regulation", Journal of Experimental Zoology. 194,pp 107-220, 1989

[21] B.S.Jha, B.P. Verma, "Effect of pesticidal mixture on protein content in the freshwater fish Clarias batracus. Journal of Ecotoxicology and Environmental Monitoring. 12(3),pp 177-180, 2002.

[22] T.Rajyalakshmi, T. Srinivas, K.V. Swamy, P. Murali Mohan, "Butachlor impact on protein, free amino acid and glutamine contents; and on activity levels of amino transferases, Glutamate Dehydrogenase and Glutamine synthetase in the freshwater snail Pila globosa (Swain Son). Biochemical and Molecular Biology International. 39(5) pp 949-960, 1996.

[23] Y. Hashimoto, Y. Wishiheuti ,in IVPAC pesticides chemistry, Human Welfare and the Environment. J.Miyamoto and P.C.Kearney,(eds.). Pergamon Press, New York, 2,pp 355-358,1983.

[24] S.Durairaj, V.R.Selvarajan, "Influence of quinalphos an organo phosphorous pesticide, on the biochemical constituents of the tisues of fish, Oreochromis mossambicus", Journal of Environmental Biology. 13(3),pp 181-185, 1992.

[25] M.B.Abou-Donia,D.M. Lapadul, C.D.Carrington, "Biochemical methods for assessment of neurotoxicity" in Perspectives in Basic and Applied Toxicology (ed. Ballentyne), Butterworth \& Co. Ltd., London, pp 130,1988.

[26] Abhay Singh Yadav, Anita Bhatnagar, Manjeet Kaur," Aberrations in the chromosomes of Cirrhinus mrigala (Hamilton) upon exposure to Butachlor", Iranian Journal of Toxicology. 7,(21), Summer 2013

[27] R.K. Gautam, K. Gautam, Tejeshwarilal , "Effects of pesticides on gastro intestinal nucleic acids in Channa punctata. Journal of Ecotoxicology and Environmental Monitoring. 12(1), pp 57-60, 2002.

[28] H.J. Evans, "Molecular mechanisms in the induction of chromosomal aberration", in Progress in Genetic Toxicology (eds: D. Scott, et al.) Elsevier Noith Holland Biomedical Press, Amsterdam, pp 57-67, 1977.

[29] A. Mashinchian Moradi, M. Alidoust Salimi, M. H. Shahhosseini, P. Alidoust Salimi, "Assessment of DNA damage induced by butachlor on Cyprinus carpio (L. 1758) using Single Cell Gel Electrophoresis International Journal of Marine Science and Engineering. 2(4),pp 233-238, Autumn 2012.
[30] J. Brachet, in The nucleic acids, Academic Press, New York. 2, 1955

[31] F.J.Bulow, "RNA-DNA ratio as indicators of recent growth rates of a fish", Journal of Fish Research. 27, pp 2343-2349, 1970.

[32] D.Geraldine, P.S. Bhavan, J. Kalimurthy, Z. Zayapragassarzon, "Effect of dichlorvos intoxication in the freshwater prawn, Machrobrachium molcolmsonii" Journal of Environmental Biology. 20,pp 141-148, 1999.

[33] S. EI-Khodary, A. Habeen, A. Haliem, "Effects of the herbicides tribunil on root mitosis of Allium сера", Ctologialogy.55,pp 209-215, 1990.

[34] M.S.Raman, G.N. Bhattacharia, "Effects of pesticide (atrazine) on cell nuclei of Lathyrus sativum (Lalin). Journal of Cytology and Genetics. 19,pp 33-37, 1984.

[35] S.K.Mansour, "Cytological effects of the herbicide tribunil on Vicia faba L." Egyptian Journal of Botany. 27, 191-198, 1984.

[36] C.M.Hendrickson, J.A. Bowden, "In vitro inhibition of LDH by insecticidal PCB mechanism of inhibition possible association of reduced Nicolinamide adenosine dineucleotide with Micrex. Journalof Agriculture and Food Chemistry. 24(2),pp 241-244, 1976.

[37] A.P. Abston, J.D.Youbrough, "The in vivo effect of mirex on soluble hepatic enzymes in rat. Pesticide Biochemistry and Physiology. 6,pp 192, 1976.

[38] D.C. Ray, J.E. Cremer, "The action of deltamethrin (a synthetic pyrethroid) on the rat. Pesticide Biochemistry and Physiology. 10, pp 333-340, 1979.

[39] K.S.Tilak, K. Satyavardhan, P.B. Thathaji, "Biochemical changes induced by fenvalerate in the freshwater fish Channa punctata. Journal of Ecotoxicology and Environmental Monitoring.13 (4), pp 261-270, 2003.

[40] D.W.Martin, P.A. Mayers,V.S. Rodwell, in Harper's Review of Biochemistry, Lange Medical Publications, Meruzen, Asia.1983.

[41] G.M.Natarajan, “ Effect of lethal $\mathrm{LC}_{50}, 48 \mathrm{~h}$ concentrations of metasystox on selected oxidative enzymes, tissues respiration and histology of gill of freshwater air breathing fish Channa striatus" Current Science. 50(22), pp 985-991, 1981.

[42]T.K.Ghosh, "Toxic impact of three organophosphate pesticides on carbohydrate metabolism in a freshwater Indian catfish Clarias batrachus" Proceedings of Indian National Science Academy. B53 (2), pp 135-142, 1987.

[43] G.M.Natarajan, "Effect of sublethal concentration of metasystox on selected oxidative enzymes, tissue respiration, and haematology of the freshwater air breathing fish, Channa striatus (Bleeker)", Pesticide Biochemistry and Physiology. 21, pp194-198, 1984.

[44] D.J. Fluke, "Temperature dependence of the direct action of ionizing radiation on beef heart lactate dehydrogenase enzyme activity, substrate and coenzyme affinities", Radiational Research. 51(1),pp 56-71, 1972.

[45] K. Veeraiah, M.K. Durga Prasad, "Studies on ventilatory patterns of fish under normal and stressed conditions using indigenously designed electronic recording instrument", Proceedings of the International Conference of ICIPACT-2001. 